\title{
Front Matter: Volume 6828
}

, "Front Matter: Volume 6828," Proc. SPIE 6828, Light-Emitting Diode

Materials and Devices II, 682801 (17 January 2008); doi: 10.1117/12.783394

SPIE. Event: Photonics Asia 2007, 2007, Beijing, China 


\title{
PROCEEDINGS OF SPIE
}

\section{Light-Emitting Diode Materials and Devices II}

\author{
Jian Wang \\ Changhee Lee \\ Hezhou Wang \\ Editors
}

\section{2-14 November 2007 \\ Beijing, China}

Sponsored by

SPIE - COS-Chinese Optical Society

Cooperating Organizations

OSJ-Optical Society of Japan • OSK-Optical Society of Korea - Australian Optical Society • Optical Society of Singapore $\bullet$ Beijing Institute of Technology (China) • Beijing University of Posts and Telecommunication (China) • Peking University (China) • Tsinghua University (China) • Zhejiang University (China) • Changchun University of Science and Technology (China) • University of Shanghai for Science and Technology (China) • Shanghai Jiao Tong University (China) • Tianjin University (China) Nankai University (China) - Shanghai Institute of Optics and Fine Mechanics (China) • Changchun Institute of Optics and Fine Mechanics (China) • Institute of Semiconductors (China) • Institute of Optics and Electronics (China) - Shanghai Institute of Technical Physics (China) • China Instrument and Control Society • China Solid State Lighting Research and Industry Alliance • Optoelectronics Technology Committee, COS (China)

Supporting Organizations

CAST_China Association for Science and Technology (China) - NNSF-National Nature Science Foundation (China) • The Ministry of Science and Technology (China)

Published by

SPIE

Volume 6828 
The papers included in this volume were part of the technical conference cited on the cover and title page. Papers were selected and subject to review by the editors and conference program committee. Some conference presentations may not be available for publication. The papers published in these proceedings reflect the work and thoughts of the authors and are published herein as submitted. The publisher is not responsible for the validity of the information or for any outcomes resulting from reliance thereon.

Please use the following format to cite material from this book:

Author(s), "Title of Paper," in Light-Emitting Diode Materials and Devices II, edited by Jian Wang, Changhee Lee, Hezhou Wang, Proceedings of SPIE Vol. 6828 (SPIE, Bellingham, WA, 2007) Article CID Number.

ISSN 0277-786X

ISBN 9780819470034

Published by

SPIE

P.O. Box 10, Bellingham, Washington 98227-0010 USA

Telephone +1 3606763290 (Pacific Time) · Fax +1 3606471445

SPIE.org

Copyright (c) 2008, Society of Photo-Optical Instrumentation Engineers

Copying of material in this book for internal or personal use, or for the internal or personal use of specific clients, beyond the fair use provisions granted by the U.S. Copyright Law is authorized by SPIE subject to payment of copying fees. The Transactional Reporting Service base fee for this volume is $\$ 18.00$ per article (or portion thereof), which should be paid directly to the Copyright Clearance Center (CCC), 222 Rosewood Drive, Danvers, MA 01923. Payment may also be made electronically through CCC Online at copyright.com. Other copying for republication, resale, advertising or promotion, or any form of systematic or multiple reproduction of any material in this book is prohibited except with permission in writing from the publisher. The CCC fee code is 0277-786X/08/ $\$ 18.00$.

Printed in the United States of America.

Publication of record for individual papers is online in the SPIE Digital Library.

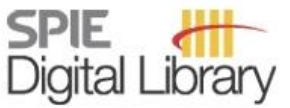

SPIEDigitalLibrary.org

Paper Numbering: Proceedings of SPIE follow an e-First publication model, with papers published first online and then in print and on CD-ROM. Papers are published as they are submitted and meet publication criteria. A unique, consistent, permanent citation identifier (CID) number is assigned to each article at the time of the first publication. Utilization of CIDs allows articles to be fully citable as soon they are published online, and connects the same identifier to all online, print, and electronic versions of the publication. SPIE uses a six-digit CID article numbering system in which:

- The first four digits correspond to the SPIE volume number.

- The last two digits indicate publication order within the volume using a Base 36 numbering

system employing both numerals and letters. These two-number sets start with $00,01,02,03,04,05$, 06, 07, 08, 09, OA, OB ... 0Z, followed by 10-1Z, 20-2Z, etc.

The CID number appears on each page of the manuscript. The complete citation is used on the first page, and an abbreviated version on subsequent pages. Numbers in the index correspond to the last two digits of the six-digit CID number. 


\section{Contents}

$\begin{array}{ll}\text { vii } & \text { Conference Committee } \\ \text { ix } & \text { Symposium Committees }\end{array}$

SESSION 1 ORGANIC OPTOELECTRONIC MATERIALS I

682802 Bipolar host materials for red and green phosphorescent OLED (Invited Paper) [6828-35]

J. H. Kwon, T. J. Park, W. S. Jeon, J. J. Park, Kyung Hee Univ. (South Korea)

682805 Small molecules with ambipolar transporting properties for efficient OLEDs [6828-34]

L. Duan, P. Wei, Y. Qiu, Tsinghua Univ. (China)

\section{SESSION 2 ORGANIC OPTOELECTRONIC MATERIALS II}

682806 Electrochemical properties of regioregular head-to-tail oligothiophenes-functionalized 9,9'-spirobifluorene derivatives (Invited Paper) [6828-47]

J. Pei, Peking Univ. (China) and National Univ. of Singapore (Singapore); J. Ni, National Univ. of Singapore (Singapore)

682807 Organic luminescent nanowires: fabrication and characterization [6828-30]

A. M. C. Ng, A. B. Djurišić, W. K. Chan, The Univ. of Hong Kong (Hong Kong China)

682808 The effect of polymer molecular weight and Coumarin 6: solvent interaction on photoluminescence spectra [6828-20]

E. Mohajerani, F. Farajollahi, R. Mahzoon, Shahid Beheshti Univ. (Iran)

682809 A stable red emission in polymer light-emitting diodes based on phenothiazine derivative [6828-18]

H. Cao, Z. Chen, Y. Liu, Peking Univ. (China); J. Li, S. Cao, Zhengzhou Univ. (China); L. Xiao, Peking Univ. (China); S. Xu, Zhengzhou Univ. (China); Q. Gong, Peking Univ. (China)

\section{SESSION 3 ORGANIC OPTOELECTRONIC MATERIALS III}

6828 OA Red light emitting compounds based on 3D conjugated structure with intramolecular charge transfer (Invited Paper) [6828-41]

F. Bai, Institute of Chemistry (China); Q. He, Shanghai Institute of Microsystem and Information Technology (China); W. Liu, Y. Zhou, Q. Sun, Y. Li, Institute of Chemistry (China)

$6828 \mathrm{OB} \quad$ Organic white light-emitting diodes using a new DCM derivative as a doping molecule [6828-52]

D.-H. Hwang, J.-D. Lee, Kumoh National Institute of Technology (South Korea); H.-J. Cho, N. S. Cho, S. K. Lee, H.-K. Shim, Korea Advanced Institute of Science and Technology (South Korea); C. Lee, Seoul National Univ. (South Korea) 
6828 OD Color tunable conductive vinyl copolymers for OLED applications [6828-02]

L. M. Leung, Y.-C. Law, M. Y. Wong, L.-Y. Tang, Hong Kong Baptist Univ. (Hong Kong China)

6828 OE Synthesis, characterization, and electroluminescent properties of a new rare earth europium complex [6828-08]

F. Wei, Changchun Univ. of Science and Technology (China) and Northeast Normal Univ.

(China); B. Wang, Changchun Univ. of Science and Technology (China); B. Wang, B. Li,

D. Xie, Northeast Normal Univ. (China)

\section{SESSION 4 ORGANIC OPTOELECTRONIC DEVICES I}

6828 OG Methods for balanced charge carriers and enhanced efficiency of organic phosphorescent devices (Invited Paper) [6828-39]

B. D. Chin, N. S. Kang, Korea Institute of Science and Technology (South Korea); H.-I. Baek,

C. Lee, Seoul National Univ. (South Korea)

6828 ol Highly efficient red light-emitting devices using copolymer containing charged iridium complex in the side chain [6828-45]

L. Wang, B. Du, Y. Cao, J. Wang, South China Univ. of Technology (China)

$6828 \mathrm{OJ}$ Study of a new type anode of OLED by MIC poly-Si [6828-09]

Y. Li, Z. Meng, C. Wu, Nankai Univ. (China); W. Man, K. S. Hoi, The Hong Kong Univ. of

Science and Technology (Hong Kong China); S. Xiong, Nankai Univ. (China)

\section{SESSION 5 ORGANIC OPTOELECTRONIC DEVICES II}

6828 OK Coupling of light from an LED into a very thin light guide by a coupling lens [6828-01]

J. H. Lee, Kongju National Univ. (South Korea); W. Chang, D. Choi, Korea Institute of Machinery and Materials (South Korea)

$6828 \mathrm{OL}$ Saturated red light emitting polymers and devices (Invited Paper) [6828-49]

Y. Shao, W. Xu, N. Liu, L. Yin, Q. Hou, Y. Xu, W. Zeng, L. Wang, S. Han, J. Wang, J. Peng,

Y. Cao, South China Univ. of Technology (China)

$6828 \mathrm{OM}$ Host engineering for high efficiency in phosphorescent organic light emitting diodes (Invited Paper) [6828-48]

S. H. Kim, Seoul National Univ. (South Korea); K. S. Yook, J. Y. Lee, Dankook Univ.

(South Korea)

682800 Enhanced electron injection in inverted top-emitting OLEDs with $\boldsymbol{n}$-Si cathode by using $\mathrm{Cs}_{2} \mathrm{CO}_{3}$ buffer layer [6828-16]

S. Chen, Y. Yuan, J. Lian, Z. Xie, X. Zhou, Sun Yat-Sen Univ. (China)

6828 OP Improved efficiency in top-emitting OLEDs with p-type Si anode [6828-15]

Y. Yuan, S. Chen, J. Lian, Z. Xie, X. Zhou, Sun Yat-Sen Univ. (China) 
6828 OR Study on the degradation of PLEDs by in-situ micro-Raman spectroscopy [6828-44]

X. Xu, Z. Qin, Nankai Univ. (China); H. Lin, Univ. of Missouri, Columbia (USA); W. XU, South China Univ. of Technology (China)

\section{SESSION 7 INORGANIC DEVICES I}

6828 OV The fabrication of high-brightness and high-power InGaAIP single-side red LED (Invited Paper) [6828-26]

P. Niu, X. Wang, W. Guo, H. Luo, X. Fu, H. Liu, X. Li, G. Yang, T. Gao, X. Yu, H. Tian, Tianjin Polytechnic Univ. (China)

6828 OW Effects of pretreatment for sapphire on GaN optical propertities (Invited Paper) [6828-17] D. Peng, Y. Feng, R. Zheng, H. Niu, Shenzhen Univ. (China)

6828 0X Online non-contact detection for LED chips [6828-28]

P. Li, L. Li, J. Wen, Y. Wen, Chongqing Univ. (China)

6828 OY Study on chroma balance based on grating spectrometer for LED [6828-04]

W. Sun, S. Wang, Y. Yin, X. Rong, Harbin Normal Univ. (China); Z. Meng, Changchun Institute of Optics, Fine Mechanics and Physics (China)

\section{SESSION 8 INORGANIC DEVICES II}

682810 A new golden bump making method for high power LED flip chip [6828-29]

H. Liu, P. Niu, Tianjin Polytechnic Univ. (China); H. Hu, H. Chen, Institute of Semiconductors (China); Z. Xia, Tianjin Polytechnic Univ. (China)

$682811 \quad$ Enhancing the light extraction efficiency of GaN-based LEDs [6828-27]

P. Niu, Y. Li, X. Li, H. Liu, H. Tian, T. Gao, G. Yang, Tianjin Polytechnic Univ. (China)

\section{SESSION 9 INORGANIC MATERIALS AND APPLICATIONS}

682813 Lasing with the shortest wavelength in substituted $\mathrm{ZnO}$ and lasing of ZnO microcrystal or scattering gain medium in closed microcavity (Invited Paper) [6828-42]

C.-R. Ding, X.-T. Long, B.-C. Chen, S.-W. Li, H.-Z. Wang, Sun Yat-Sen Univ. (China)

682814 Effect of hydrogen dilution on photoluminescent properties of nanocrystalline SiC films deposited by helicon wave plasma CVD [6828-19]

W. Yu, J. Du, L. Zhang, S. Cui, L. Han, G. Fu, Hebei Univ. (China)

682815 Synthesis and luminous characteristics of $\mathrm{Ba}_{2} \mathrm{SiO}_{3} \mathrm{Cl}_{2}: \mathrm{Eu}^{2+}, \mathrm{Mn}^{2+}$ phosphor for white LED [6828-06]

C. Shen, China Jiliang Univ. (China) and Zhejiang Univ. (China); Y. Yang, S. Jin, China Jiliang Univ. (China) 
682816 Color uniformity and data simulation in high-power RGB LED modules using different LEDchips arrays [6828-25]

Y. Tu, S. Jin, Y. Wang, L. Dou, China Jiliang Univ. (China)

682817 A novel submersible phytoplankton fluorometer with multi-wavelength light emitting diode array as excitation source [6828-05]

Z. Wang, Univ. of Science and Technology of China (China) and Anhui Institute of Optics and Fine Mechanics (China); W. Liu, Y. Zhang, W. Sima, J. Liu, Anhui Institute of Optics and Fine Mechanics (China)

\section{POSTER SESSION}

682818 Trans-cis-trans photoisomerization as an all-optical switching in azo-dye-doped polymer waveguide [6828-22]

E. Mohajerani, E. Heydari, Shahid Beheshti Univ. (Iran)

Author Index 


\title{
Conference Committee
}

\author{
Conference Chairs \\ Jian Wang, South China University of Technology (China) \\ Changhee Lee, Seoul National University of Technology (South Korea) \\ Hezhou Wang, Zhongshan University (China)
}

Program Committee

Gang Yu, CBrite, Inc. (USA)

Ching W. Tang, University of Rochester (USA)

Yanbing Hou, Beijing Jiaotong University (China)

Yong Qiu, Tsinghua University (China)

Franky So, University of Florida (USA)

Yuguang Ma, Jilin University (China)

\section{Session Chairs}

1 Organic Optoelectronic Materials I

Changhee Lee, Seoul National University (South Korea)

Jian Pei, Peking University (China)

2 Organic Optoelectronic Materials II

Fenglian Bai, Institute of Chemistry (China)

Jang H. Kwon, Kyung Hee University (South Korea)

3 Organic Optoelectronic Materials III

Byung Doo Chin, Korea Institute of Science and Technology (South Korea)

4 Organic Optoelectronic Devices I

Junbiao Peng, South China University of Technology (China)

$5 \quad$ Organic Optoelectronic Devices II

Xiaoxuan Xu, Nankai University (China)

6 Process and Applications

Jian Wang, South China University of Technology (China)

7 Inorganic Devices I

Jun Ho Lee, Kongju National University (China) 
8 Inorganic Devices II

Pingjuan Niu, Tianjin Polytechnic University (China)

9 Inorganic Materials and Applications

Ruisheng Zheng, Consultant (USA) 


\title{
Symposium Committees
}

\author{
General Chairs \\ Brian Culshaw, University of Strathclyde (United Kingdom) \\ Bingkun Zhou, Tsinghua University (China) and COS-Chinese Optical \\ Society (China) \\ General Cochairs
}

Arthur Chiou, National Yang-Ming University (Taiwan, China)

Mitsuo Takeda, University of Electro-Communications (Japan)

Chungli Bai, Chinese Academy of Sciences (China)

Seung-Han Park, Yonsei University (South Korea)

Zhizhan Xu, Shanghai Institute of Optics and Fine Mechanics

(China)

Jianlin Cao, China Ministry of Science and Technology (China)

Junhao Chu, Shanghai Institute of Technical Physics (China)

Jingming Kuang, Beijing Institute of Technology (China)

Xiaomin Ren, Beijing University of Posts and Telecommunications (China)

Dingbo Kuang, Shanghai Institute of Technical Physics (China)

Guozheng Yang, Institute of Physics (China)

Honorary Chairs

Daheng Wang, Chinese Academy of Sciences (China)

Guoguang Mu, Nankai University (China)

Technical Program Chair

Songlin Zhuang, Shanghai University of Science and Technology (China)

Technical Program Cochairs

Xun Hou, Xian Institute of Optics and Precision Mechanics (China)

Qian Mao, Wuhan Research Institute of Posts and Telecommunications (China)

Xu Liu, Zhejiang University (China)

Local Organizing Committee Chair

Shusen Xie, Fujian Normal University (China)

Local Organizing Committee Cochairs

Guoqiang Ni, Beijing Institute of Technology (China)

Qihuang Gong, Peking University (China)

Ying Gu, PLA General Hospital (China)

Huilin Jiang, Changchun University of Science and Technology (China) 
General Secretary

Guoqiang Ni, Beijing Institute of Technology (China)

Administrative Vice General Secretary

Boyu Ding, Beijing Institute of Technology (China)

Vice General Secretaries

Hanyi Zhang, Tsinghua University (China)

Ya Cheng, Shanghai Institute of Optics and Fine Mechanics (China)

Zhongwei Fan, Academy of Opto-electronics (China)

Jianxin Chen, Fujian Normal University (China)

Lan Wu, Zhejiang University (China)

Shaowen Wang, COS-Chinese Optical Society (China)

Yuejin Zhao, Beijing Institute of Technology (China)

Chongxiu Yu, Beijing University of Posts and Telecommunication (China)

Jun Ruan, China Solid State Lighting Research and Industry Alliance

(China)

Local Organizing Committee Members

Kangnan Qi, Beijing Optical Society (China)

Chunqing Gao, Beijing Institute of Technology (China)

Tiegen Liu, Tianjin University (China)

Lanxing Shao, Shanghai Optical Society (China)

Zaixuan Zhang, Chinese Jiliang University (China)

Hongda Chen, Institute of Semiconductors (China)

Baosheng Liu, Beijing Optical Society (China)

Xin Wang, Hubei Optical Society (China)

Lin Zhai, COS-Chinese Optical Society (China)

Zhiqiang Zhu, East China Normal University (China)

Lei Xu, Fudan University (China)

Hezhou Wang, Zhongshan University (China)

Zhiming Yi, Ofstar Tech Company, Ltd., Shenzhen (China) 